\title{
Review on Seismic Analysis of Elevated Water Tank with Different Staging Configuration
}

\author{
Vrushali Gujar $^{1}$ \\ U.G. Student, \\ Department of Civil Engineering, \\ G H Raisoni University, M.P
}

\author{
Shahayajali Sayyed ${ }^{2}$ \\ Asst. Professor, \\ Department of Civil Engineering, \\ G H Raisoni University, M.P
}

\begin{abstract}
Water tank is used for storage of water. Direct source of water in water tank is from the rainfall. Taking water from tank for irrigation purpose is economical in that place where construction of well is costly. Water obtained from elevated water tank is useful for domestic purpose. Such as drinking, cooking, washing purpose. Elevated water tanks are integrated part of lifeline facilities elevated water tank is storage container construction for the purpose of holding water supply. A large number of water tank is damage during past earthquake. So, there is need to focus on seismic safety.

The aim of this paper to propose a seismic response of intz tank for different type of staging such as frame staging, shaft staging of water tank \& select one which have best earthquake resistance behavior . To study dynamic \&static analysis of water tank by using staad-pro software.
\end{abstract}

Keyword:-Water tank, staging, Seismic analysis

\section{INTRODUCTION:-}

Water tank are used for agriculture, firefighting, drinking. Failure of water tank has a negative impact on a performance of water network.

Earthquake is the major cause of failure of water tank so. Structure should be design in such a way that it have the ability to withstand against the seismic force. In this review paper we will study intz tank for different type of staging i.e. Frame staging \& shaft staging.

The aim of design of this tank to have seismic resistance propose . Comparative study of frame staging \&shaft staging will be done. In this paper we will study the behaviors of different staging under different loading condition, this can be done using Staad-Pro software.

\section{SCOPE OF THE STUDY:-}

To know design philosophy for safe and economical design of intz water tank.To study seismic response of intz water tank for various zone of earthquake (Zone II,III,IV,V)

\section{OBJECTIVE OF THE STUDY:-}

1. To determine seismic effect on elevated intz water tank with different staging system .

2. To determine base shear on water tank.

\section{LITERATURE REVIEW:-}

Prashant A Bansode ${ }^{1}$ in his review paper he entitled seismic analysis of elevated water tank with different staging configuration . he studied the behavior of different staging system under different tank condition ,Response Spectrum Analysis is carried out on three different types of bracing system of elevated water tank for various types of zone by using staad-pro v8i 2007 .he did comparison of base shear and nodal displacement of elevated water tank for empty and full condition. In his study he got the following result: Base Shear increase as the level of bracing increases because bracing system put an additional mass to the structure, which result into increase in base shear value. Base moment is found to be increases as the level of bracing increases .Lateral displacement and time period of vibration is reduced considerably because bracing system increases the stiffness of the structure which reduce the lateral displacement .

Cherukupally Rajesh ${ }^{\mathbf{9}}$ and Sudip Jha' in their review paper they entitled the behavior of elevated water tank for different staging height .In there study they focused on behavior of elevated tank under different load and safer design of structure. They considered changed in wind load behavior of elevated tank with consideration of responses such as base shear, base displacement. Finally study discloses the importance of suitable supporting configuration to remain withstand against heavy damage of elevated water tank during wind load condition.Wind load characteristics with different two basic wind speed which causes excitation of responses such as base shear force, overturning moment and roof displacement.

S.S.Quandri ${ }^{4}$ in his review paper entitled "Seismic Analysis of RC Elevated Water Tank Using Different Staging Pattern". He considered different parameter like water storage capacity, height of water tower was taken as consistent and variation in number of segment $\mathrm{h} / \mathrm{d}$ ratio ,staging arrangement such as normal staging, hexagonal staging ,cross staging and radial staging with central column are considered he considered all this parameter total 36 models for empty tank, half tank and full tank condition are created .They worked on staad-pro software based on FEM .The response of each water tower with respect to other will be check for base shear, axial force , bending moment and lateral displacement .The behavior of water is described with the help of graphs. As the structure is fixed at the base and free at top so there is an increase in stiffness and there is a change in magnitude of lateral displacement base shear.

Sonali M Pole ${ }^{10}$ in her paper entitled seismic behavior of elevated water tank under different staging pattern .In her paper she studied different staging pattern with different tank storage capacities, She worked on Staad -Pro V8i two different supporting system such as Radial bracing and 
Cross bracing are compared with basic supporting system for various fluid level condition. Tank responses including base shear, overturning moment and roof displacement have been observed .she got the following conclusion empty tank condition has less base shear and base moment compared to full tank condition .

Hardik V. Patel ${ }^{\mathbf{1 1}}$ in his paper entitled analysis of elevated square water tank with different staging system .In his paper he mainly focused on seismic analysis of RCC Square elevated tank using SAP 2000. Using response spectrum analysis compare the result of the base reaction, joint displacement with different staging system. In his paper he studied about frame type of structure .The main components of frame type of staging are column and braces. In frame staging column are arranged on periphery and it is connected internally by bracing at various levels. In elevated water tank head requirement for distribution of water is satisfied by adjusting the height of the staging portion.

Pranjali N Dhage ${ }^{\mathbf{1 2}}$ in her review paper she entitled study on dynamic analysis of RCC elevated water tank. In her paper she considered two cases for same capacity of tank change in geometric feature of container can show change in the response of elevated water tank. In her conclusion she got Static response show high scale value than that of dynamic response ,It occurs due to different picks of time period and hydrodynamic factors ignored during the analysis because it will cause collapsed of the structure.

George W Housner ${ }^{2}$ (1963) in his paper consider three basic condition for analysis of water tank. First he considered full filled water tank without free board then sloshing effect is neglected, then he considered empty water tank then no sloshing as water is absent .Full and empty water tank behave as a one mass structure but in third case water tank is partially filled, in this case effect of sloshing must be considered.. From above three cases he concluded that fully filled tank is seen maximum force to that of half full tank. He concluded maximum force to which the half full tank is subjected may be significantly less than half the force to which full tank is subjected.

\section{CONCLUSION:-}

Analysis and Design of elevated water tank against earthquake using Staad-pro V8i is considerable importance .This is done to remain structure functional even after earthquake.

After detailed study of all paper following point are to be considered at the of time of seismic analysis of elevated water tank.

1. Slossing effect must be considered.

2. Study of seismic tank behavior for different geometry.

3. Study of seismic tank behavior for different staging.

4. Dynamic and Static response on water tank studied.

5. Different types of supporting (bracing) system studied.

6. Three cases are considered
a. Empty tank
b. Fully filled tank
c. partially filled tank

Comparing seismic response of all this three tank partially filled tank show less damage compare to other two tank i.e. half filled tank and empty filled tank .

7. The effect of earthquake is not same in all zone it varies from zone to zone (Zone II, III, IV, V).

\section{REFERENCE:-}

[1] Prashant A Bansode, V P Datye "Seismic analysis of elevatedwater tank with different staging configuration"MAT journal of geotechnical studies volume 3 issue 1

[2] George w Housner (1963)"The dynamic behavior of water tank "Bulletin of the seismological society of America vol 53, No.2 page 381-387

[3] Mangulkar Madhuri N, GaikwadMadhukarV"Review on Seismic analysis of elevated water tank"International journal of Civil Engineering and Technical (IJCIET), ISSNO9766316, vol-4 isssue 2 March-April (2013) pp288-294

[4] S.S Quadri,R. M. Sawant " Seismic analysis of RC elevated water tank using different staging pattern "Internationnal journal of Structural Engineering and Analysis

[5] Sonali M. Maidankar, Prof. G.D. Dhawale ,Prof. S.G.Makarande "Seismic Analysis of elevated circular water tank using various bracing system ".International journal of Advance Engineering Research and science (UAERS)[vol2,issue-1,Jan-2015]

[6] Ms. RupalGondalia,Asstprof.Dhananjay Patel,“Non linear static (pushover) Analysis of elevated storage reservoir"International journal of advance Engineering and Research development volume 4,issue 4,April2017

[7] Afshin Mellati "Predicting Dynamic capacity curve of elevated water tank "A pushover procedure Civil Engineering Journal vol.4,no. 11,November 2018

[8] Parth D. Daxini Prof. Tarak P. Vara"Review on Seismic analysis of elevated storage reservoir "International journal for scientific research and Development vol.3 ,issue 112016 /ISSN (Online):2321-0613

[9] Cherukupally Rajesh and SudipJha ,Prof.P.Shrilakshmi "Seismic Behavior of an elevated water tank for different staging height" ,International journal and magazine of Engineering Technology, Management and Research

[10] Sonali M. Pole Prof. Amey R. Khedikar Seismic Investigation of RC elevated water tank for different types of staging system " International journal of Innovative Research in Seismic Engineering and Technology vol. 6, Issue 7,July 2017

[11] Hardik V Patel, Prof Jasmin A Gandhiya and Prof. Abhishek Raturi" Analysis of elevated square water tank with different staging system", International journal of Innovative Science and Research Technology

[12] Ms Pranjali N. Dhage ,Mr. Mandar M. Joshi,Review study an dynamic analysis of RCC elevated water tank", International journal of emerging Technologies and Innovative Research

[13] Shahayajali Sayyed "Comparative Analysis of Beam-Column Joint of Elevated Water Tank" IJSART - Volume 3 Issue 10 october 2017

[14] Mr. Mani Shankar Jha, Mr. Shahayajali Sayyed "Review on Seismic Analysis of Intze Water Tank with different staging configuration" IJRAR June 2019, Volume 6, Issue 2.

[15] Miss. Shivani S Tumsare, Mr.Shahayajali Sayyed "Review on Seismic Analysis of Elevated Intze Water Tank with different staging configuration" IJRAR June 2019, Volume 6, Issue 2. 